\title{
STUDY ON THE THERAPEUTIC POTENTIAL OF MELISSA OFFICINALIS (LEMON BALM) ON MALE WISTAR ALBINO RATS WITH INDUCED-HYPOTHYROIDISM.
}

\section{BY}

\author{
El-Yamany I. El-Zwahry ${ }^{1}$, Khaled G.Abdel-Wahhab ${ }^{2}$, Hesham G. AbdelRashed ${ }^{1}$, Hagar H. \\ Murad $^{2}$, Mohamed H.M. Abdel-Aziz ${ }^{1 *}$
}

FROM

${ }^{1}$ Zoology Department, Faculty of Science, (Boys) Al-Azhar University, Egypt

${ }^{2}$ Medical Physiology Department, National Research Centre, Doki, Egypt

\begin{abstract}
This study aimed to evaluate the potential improvement of Melissa Officinalis Ethanolic Extract (MEE) against propylthiouracil induced-hypothyroidism. After acclimatization, 50 male Wistar albino rats were randomly divided into five groups; group 1) normal control rats, group 2) normal rats administrated orally with (75 mg/kg) MEE for 60 days, group 3) hypothyroidism-induced rats, group 4) hypothyroidism rats treated orally with Eltroxin ${ }^{\circledR}$ drug $(100 \mathrm{ug} / \mathrm{kg})$, and group 5) hypothyroidism rats treated with MEE (75 $\mathrm{mg} / \mathrm{kg}$ ). The obtained results revealed that hypothyroidism induction resulted in reduction in the thyroid hormones and affect negatively on the liver and kidney tissues as well as deteriorate their oxidative status. MEE therapy succeeded in amelioration of thyroid function towards normal level without any unfavorable effects on the body physiology as it contains many safe phytochemical compounds. In conclusion, MEE possesses antihypothyroidism efficacy and antioxidant properties.
\end{abstract}

Key words: Hypothyroidism, Melissa, Rats, Extracts, Antioxidant

\section{Introduction}

Hypothyroidism is a condition in which the thyroid gland fails to produce a sufficient amount of thyroid hormone to meet the metabolic demands of the body. Hypothyroidism is accompanied with an elevation level of serum thyrotropin stimulating hormone (TSH) in combination with low thyroxine (T4) or triiodothyronine (T3) levels. Hypothyroidism, constitutes the most common endocrine abnormality in recent years. Thyroid hormones (T4) and (T3) play an important role in all major metabolic pathways. They regulate the basal energy expenditure through their effect on protein, carbohydrate and lipid metabolism Cachefo et al (2001). Thyroid hormones exert profound effects in the regulation of glucose and insulin secretion Ahmad et al (2013). It has been thought to be associated with obesity; and is the second most common endocrinopathy during pregnancy and its incidence range from $2 \%$ to $5 \%$. (also known as Hashimoto's thyroiditis) and iatrogenic thyroid gland destruction as a therapeutic measure for hyperthyroidism are the most common etiologies for this endocrinopathy in pregnant women Smallridge and Ladenson (2001). 
Propylthiouracil (PTU) has been used in the management of hyperthyroidism for more than half a century; it is frequently used as anti-thyroid agents, so it can be used for hypothyroidism animal modeling Reza Hedari et al (2014).

For centuries people across the countries have been using natural products as plant based dietary supplements for weight control and treatment Gosh (2009). Herbal drugs are gradually becoming more acceptable, as they are believed to be safe Panda and Kar (2005). Melissa (Melissa officinalis L, Lamiaceae) is a plant cultivated in some parts of Iran and known as lemon balm; its leaves are used in Iranian folk medicine for their digestive, carminative, antispasmodic, sedative, analgesic, tonic and diuretic properties, gastrointestinal disorders. This plant has many therapeutic effects including antimicrobial activity (anti-parasitic, antibacterial, antiviral, antifungal, etc.). Then, its antioxidant properties are to overviewed. Various studies have shown that Melissa officinalis possesses a high amount of antioxidant activity through its chemical components including high amount of flavonoids, rosmaric acid, gallic acid and phenolic contents. Miraj et al (2016). Many studies confirmed the antioxidative effects of Melissa officinalis; thus, its effect in preventing and treating oxidative stress-related diseases might be reliable. It is applied to the treatment of Alzheimer Pereira et al (2009); Miraj et al (2016). Research has shown that this herb can calm the patients in their behavior, improve their learning, and enhance their short-term memory. Akhondzadeh et al (2003). Also, M. officinalis extracts showed some nicotinic and muscarinic activity Wake et al (2000); Akhondzadeh et al (2003). Therefore, the main objective of this study was to explore the possible potential therapeutic role of the ethanolic extract of Melissa towards induced-hypothyroidism in rat model.

\section{Materials and Methods}

\section{Herbal extraction}

Melissa (Melisa officinalis) herb was Purchase from Abd El-Rahman Harraz (Bab El-Khalk zone, Cairo, Egypt), identified and authenticated by scientific botanists at Botany Department, Faculty of Science, (boys) Al-Azhar University in Cairo and found to have taxonomic serial number (TSN) 32565. The ethanolic extraction process was carried out according to the method of Zarei et al (2014). Officinalis dry leaves were cleaned, dried, powdered and eventually poured into a capped glass container and was mixed with ethanol $96 \%$. The mixture was allowed to mix well for 72 hours, filtered and dried via rotary evaporator and stored at $4^{\circ} \mathrm{C}$ till use.

\section{Animals and experimental design}

Fifty Adult male Wistar albino rats (Rattus norvegicus) weighting 150-170g were obtained from Egyptian Holding Company for Biological Products and Vaccines, Hellwan Farm, Helwan, Cairo, Egypt. The animals were housed in suitable plastic cages for one week for acclimation before the experimental study at animal house of Zoology Department, Faculty of Science, Al-Azhar University. Excess tap water and standard rodent food pellets $[20.3 \%$ protein , (20\% casein and $0.3 \%$ DL-Methionine), $5 \%$ fat (corn oil), $5 \%$ fibers, $3.7 \%$ salt mixture and 1\% vitamin mixture; obtained from Meladco Company for animals and rodents food pellets, El-Obour City, Cairo, Egypt] were always available. All animals received human care in compliance with the standard insitiuations criteria as cited 
by animal ethical committee number FWA00014747, National Research Centre. After the animals being acclimatized with experimental room conditions, they were divided into five groups (10 rats each group) as following: group 1: normal rats and acting as control group and were orally given $0.5 \mathrm{ml}$ physiological saline daily for 60 days and fed normal diet; group 2) normal the rats administered orally with $75 \mathrm{mg} / \mathrm{kg} /$ day of dried Melissa officinalis ethanolic extract (MEE) dissolved in saline for 60 day and fed normal diet; group 3) hypothyroidism-induced rats fed normal diet [hypothyroidism was induced as reported by Hang et al (2005) through administration with $16.8 \mathrm{mg} / \mathrm{kg}$ of propylthiouracil for 60 days]; group 4) hypothyroidism-induced rats treated orally with anti-hypothyroidism pharmaceutical drug Eltroxin ${ }^{\circledR}$ at a dose of $100 \mathrm{ug} / \mathrm{kg} /$ day for a similar period and fed normal diet; and group 5) hypothyroidism-induced rats treated orally with MEE at dose of $75 \mathrm{mg} / \mathrm{kg} / \mathrm{day}$ dissolved in saline for 30 days same duration.

\section{Body weight gain}

After induction of hypothyroidism in rats, body weights of both hypothyroid and normal rats groups were recorded at start and end of the experiment; and the percentage of weight gain was calculated according to the formula.

Body weight gain $(\%)=\frac{W 2-W 1}{W 1} * 100$

W1 is the animals' weight at start.

W2 is the animals' weight at the end of the experiment.

\section{Blood sampling}

At the end of study period (60 days), animals were fasted overnight, and following diethyl-ether anesthesia, blood sample specimens ( were drawn from the retro-orbital plexus using sterile heparinized glass capillary (single draw vacutainer needle) in two portions. A portion of $0.5 \mathrm{ml}$ blood was collected in heparinized tube for hemoglobin determination; the other blood portion was drown into open vacutainer collecting tubes and left for 10 minutes to clot then centrifuged at $3000 \mathrm{rpm}$ for 20 minutes using cooling centrifuge (Andreas Hettich GmbH \& Co. 12 D-78532 Tuttlingen Germany). Finally the sera were separated at once, divided into aliquots and stored at $-80^{\circ} \mathrm{C}$ until biochemical parameters measurement.

\section{Liver and kidney tissues homogenate preparation}

After blood collection, animals were rapidly sacrificed and one part of the livers (left lobe) and the left kidney from each animal were dissected out, washed with saline, dried, rolled in a piece of aluminum foil and stored at $-80^{\circ} \mathrm{C}$ until homogenization and biochemical determinations.

\section{Homogenate preparation}

A specific weight of both liver and kidney was subjected to homogenization in icecold phosphate buffer $(50 \mathrm{mM}, \mathrm{pH} 7.4)$ to give $10 \%$ homogenate (w/v i.e each $10 \mathrm{ml}$ of the homogenate equivalent to one gram tissue); the homogenates were cool centrifuged at 9000 
rpm for 20 min and the supernatant was separated, divided into aliquots and stored at $-80^{\circ} \mathrm{C}$ until determination of biochemical parameters.

\section{determination of biochemical parameters}

All the biochemical measurements were carried out using spectrophotometer (Cary 100 UV-Vis), USA. Hemoglobin level was determined according to the method of Serum glucose level was determined according to the CHOP-PAP method by photometric system described by Tietz (1995). The assay was performed according to the instruction manual of Centronic reagent kits Purchased from Vitro Scient Co, Mohamed Abaza St. Inshas Industrial Area, Belbis, Sharkia, Egypt. Serum ALAT and ASAT levels were estimated spectrophotometrically according to the method of Bergmeyer et al (1986) and Serum albumin was determined according to the method of Doumas et al (1971) and Serum triglycerides and total cholesterol were determined according to the method described by Fossati and Prencipe (1982) and LDL-cholesterol was calculated according to the following equation as stated by Judith et al (1990). Serum urea and creatinine concentrations were determined according to the method of Newman and Price (2001). respectively; using kit from Elitech Diagnostic Co. France. Serum bilirubin (total, direct and indirect bilirubin) level was determined according to the colorimetric method described by Young (2001). Serum total proteins concentration was determined according to the colorimetric method described by Tietz (1994) and Serum HDL-c level was determined according to the photometric method described by Warnick and Wood (1995). respectively; using Spectrum reagent kits (Cat. No. 266 001) Purchased from Egyptian Company for Biotechnology (S.A.E), Obour City, Cairo, Egypt. Calcium level was determined spectrophotometrically according to the kinetic methods described before by Tietz (1976) using reagent kits purchased from Diamond Diagnostic MDSS GmbH Schiffgraben 41 30175 Hannover, Germany. Uric acid level was determined according to the method described by Barham and Trinder (1972) and Determination of nitric oxide (NO) level tissue NO and GSH concentration was estimated colorimetrically according the method described by Montgomery and Dymock (1961), and Beutler et al (1963). And Glutathione peroxidase activity in tissue homogenates was carried out according to Habig et al (1974), respectively using commercial kit purchased from Bio-Diagnostic, Dokki, Giza, Egypt.

\section{Estimation of thyroid hormones}

Serum of thyroid hormones level was measured using ELISA technique; serum TSH, Total T3, T4, Free T3 and Free T4 were determined according to LIAISON using reagent kits purchased from Diasorin Company in Germany.

\section{Determination of $M D A$}

Malondialdehyde (MDA) is the most abundant individual aldehyde resulting from lipid peroxidation in biological systems and was determined according to the chemical method of Draper and Hadley (1990).

The lipid peroxidation level was calculated in nM MDA per gram liver tissue according to the following formula: 
MDA $\left(\right.$ nmol g $\left.{ }^{-1}\right)=\left[\left\{\mathrm{A}_{535} \times 10^{9} /\left(1.56 \times 10^{5}\right) \times 10^{3}\right\} \times \mathrm{AD}\right] \times 10^{-1}$. Where $1.56 \times 10^{5} \mathrm{M}^{-1} \mathrm{~L}^{-}$ ${ }^{1} \mathrm{~cm}^{-1}=$ extinction coefficient of MDA, AD = Assay dilution (10) [0.5 ml homogenate +4.5 ml working reagent].

\section{Determination of $\mathrm{Na}^{+} / \mathrm{K}^{+}$ATPase activity}

$\mathrm{Na}^{+} / \mathrm{K}^{+}$ATPase activity was measured according to the modified chemical method of Tsakiris et al (2004).

$\mathrm{Na}^{+} / \mathrm{K}^{+}$ATP-ase activity was calculated using the formula

$\left[\right.$ ATP ase activity $(\mathrm{nmol} / \mathrm{g}$ of tissue $\left.)=\frac{\text { A sample } * 0.64 \times 1.0 * 60.0}{\text { A standard } * 10 * 10}\right]$.

\section{Statistical analysis}

Comparisons between means carried out using one way ANOVA and followed by post hoc Duncan test at level of $\mathrm{p} \leq 0.05$ using statistical analysis system (SAS) program software; copyright (c) 1998 by SAS Institute Inc., Cary, NC, USA.

\section{Results}

Results of this study revealed that Melissa officinalis ethanolic extract (MEE) and hypothyroidism animal groups hadn't any unfavorable effects on the glucose level. HB level (which decreased significantly in hypothyroidism group) improved markedly towards normal level after administration on MEE or Eltroxin ${ }^{\circledR}$. Animals treated with the Melissa officinalis ethanolic extract didn't disturb the body weight gains, while hypothyroidisminduced rats showed a significant increased in BWG in compare to normal ones. In contrast, treatment of induced-hypothyroidism rats with either Eltroxin ${ }^{\circledR}$ or MEE improved the rate of body weight gain(BWG) in compare to hypothyroidism-induced rats (Table 1).

Data in table (2) showed that hypothyroidism animals induced a significant increase in serum TSH level accompanied with a significant decrease in T3, T4, FT3 and FT4 levels and mostly vice versa was in regard to MEE group when both were compared with control group. Favorably, administration of hypothyroidism animals with either Eltroxin ${ }^{\circledR}$ or MEE significantly ameliorated the levels of all thyroid hormones (TSH, T4, T3, FT3 and FT4) in compared to hypothyroidism group.

The obtained data showed that both MEE and hypothyroidism groups didn't disturb the levels of liver function parameters. Moreover, treatment of hypothyroidism animal group with Eltroxin ${ }^{\circledR}$ drug deteriorated most of liver functions as it raised significantly the activity of aminotransferase enzymes (ALAT and ASAT), while treatment with MEE did not (Table 3).

The results in table (4) showed insignificant increase in serum urea and creatinine level in both hypothyroidism and MEE treated groups when compared with control group, on contrast serum uric acid showed significant increase $(\mathrm{p} \leq 0.05)$ in both hypothyroidism and Hypothyroidism+ Eltroxin ${ }^{\circledR}$ treatment groups when compared with control. While Calcium level showed a significant decrease in hypothyroidism group when compared with control group. With respect to (Table 5), treatment of normal or hypothyroidism rats with 
MEE or Eltroxin ${ }^{\circledR}$ did not deteriorate serum total cholesterol, triglycerides, HDL or LDL values when compared with control group.

Similarly, MEE didn't damage the liver oxidative stress status as MDA, NO, GSH, GPx and ATPase levels when compared to the control group; while hypothyroidism induced a significant elevation $(\mathrm{p} \leq 0.05)$ in MDA and NO levels coupled with a significant reduction in the antioxidant potential $(\mathrm{GSH}),(\mathrm{GPx})$ and (ATPase) activity in compare to control group. On the other side treatment of hypothyroidism group, with either MEE or Eltroxin $^{\circledR}$, recorded marked improvements in the oxidative stress status; MEE performed antioxidant potential higher than did Eltroxin ${ }^{\circledR}$ (Table 6).

Table 7 shows oxidative stress status of kidney tissue, the results illustrated that administration of MEE didn't deteriorate the levels of kidney as MDA, NO, GSH, GPx and ATPase while hypothyroidism group recorded a significant elevation $(p \leq 0.05)$ in MDA and NO levels coupled with a significant reduction in the voltage of antioxidant buttery (GSH),GPx) and ATPase activity in compare to control group. On the other side, treatment of hypothyroidism group with either MEE or Eltroxin ${ }^{\circledR}$, recorded marked improvements in the kidney oxidative stress status; MEE performed antioxidant potential higher than did Eltroxin $^{\circledR}$.

Table 1. serum Glucose level, HB percent and BWG level in control hypothyroidism and hypothyroidism-treated animals groups.

\begin{tabular}{|l|l|l|l|}
\hline Groups parameters & $\begin{array}{l}\text { Glucose } \\
(\mathrm{mg} / \mathrm{dL})\end{array}$ & $\begin{array}{l}\mathrm{HB} \\
(\mathrm{g} / \mathrm{dL})\end{array}$ & $\begin{array}{l}\text { BWG } \\
(\mathrm{g} / 100 \mathrm{~g})\end{array}$ \\
\hline Control & $102 \pm 9.5^{\mathrm{A}}$ & $12.2 \pm 0.1^{\mathrm{A}}$ & $54 \pm 2.8^{\mathrm{A}}$ \\
\hline MEE & $107 \pm 10^{\mathrm{A}}$ & $11.9 \pm 0.3^{\mathrm{A}}$ & $54 \pm 3.1^{\mathrm{A}}$ \\
\hline Hypothyroidism & $118 \pm 6.5^{\mathrm{A}}$ & $10.1 \pm 0.2^{\mathrm{B}}$ & $63.6 \pm 2.4^{\mathrm{B}}$ \\
\hline Hypothyroidism + Eltroxin ${ }^{(}$ & $98 \pm 3.9^{\mathrm{A}}$ & $11.7 \pm 0.2^{\mathrm{A}}$ & $50 \pm 9.7^{\mathrm{C}}$ \\
\hline Hypothyroidism + MEE & $105 \pm 15^{\mathrm{A}}$ & $12.7 \pm 0.2^{\mathrm{A}}$ & $42 \pm 1.6^{\mathrm{A}}$ \\
\hline
\end{tabular}

All data are expressed as mean \pm standard error. Data were subjected to one-way ANOVA followed by post hoc Duncan) test. Within the same column, means with different superscript letters are significantly different at $p \leq 0.05$. MEE is Mellisa ethanolic extract, Hypo is Hypothyroidism. 
Table 2. Serum $\mathrm{T}_{3}, \mathrm{~T}_{4}, \mathrm{FT}_{3}, \mathrm{FT}_{4}$ and $\mathrm{TSH}$ levels of control, hypothyroidism and hypothyroidism-treated animals groups.

\begin{tabular}{|c|c|c|c|c|c|}
\hline $\begin{array}{c}\text { Groups } \\
\text { parameters }\end{array}$ & $\begin{array}{c}\text { T3 } \\
(\mathrm{ng} / \mathrm{dL})\end{array}$ & $\begin{array}{c}\mathrm{T} 4 \\
(\mathrm{ug} / \mathrm{dL})\end{array}$ & $\begin{array}{c}\text { FT3 } \\
(\mathrm{pg} / \mathrm{mL})\end{array}$ & $\begin{array}{c}\text { FT4 } \\
(\mathrm{ng} / \mathrm{dL})\end{array}$ & $\begin{array}{c}\text { TSH } \\
(\mathrm{uIU} / \mathrm{mL})\end{array}$ \\
\hline Control & $55 \pm 4.48^{\mathrm{C}}$ & $4.6 \pm 0.2^{\mathrm{C}}$ & $1.9 \pm 0.14^{\mathrm{C}}$ & $1.2 \pm 0.15^{\mathrm{AB}}$ & $1.1 \pm 0.24^{\mathrm{B}}$ \\
\hline MEE & $89 \pm 1.3^{\mathrm{A}}$ & $7.4 \pm 0.2^{\mathrm{A}}$ & $4.0 \pm 0.04^{\mathrm{A}}$ & $1.41 \pm 0.06^{\mathrm{A}}$ & $0.9 \pm 0.1^{\mathrm{B}}$ \\
\hline Hypothyroidism $^{\mathrm{D}}$ & $37 \pm 1.49^{\mathrm{D}}$ & $2.89 \pm 0.3^{\mathrm{D}}$ & $1.3 \pm 0.1^{\mathrm{D}}$ & $0.22 \pm 0.04^{\mathrm{C}}$ & $5.8 \pm 0.9^{\mathrm{A}}$ \\
\hline Hypo + Eltroxin $^{\circledR}$ & $75 \pm 7.0^{\mathrm{B}}$ & $7.1 \pm 0.7^{\mathrm{B}}$ & $2.77 \pm 0.2^{\mathrm{B}}$ & $1.01 \pm 0.05^{\mathrm{B}}$ & $2.3 \pm 0.2^{\mathrm{C}}$ \\
\hline Hypo + MEE & $52 \pm 2.0^{\mathrm{C}}$ & $6.77 \pm 0.8^{\mathrm{B}}$ & $2.3 \pm 0.1^{\mathrm{C}}$ & $1.11 \pm 0.12^{\mathrm{B}}$ & $1.9 \pm 0.04^{\mathrm{C}}$ \\
\hline
\end{tabular}

All data are expressed as mean \pm standard error. Data were subjected to one-way ANOVA followed by post hoc Duncan) test. Within the same column, means with different superscript letters are significantly different at $p \leq 0.05$. MEE is Mellisa ethanolic extract, Hypo is Hypothyroidism.

Table 3. Liver functions of control, hypothyroidism and hypothyroidism-treated animals groups.

\begin{tabular}{|l|l|l|l|l|l|l|l|}
\hline $\begin{array}{r}\text { Groups } \\
\begin{array}{r}\text { par } \\
\text { ame } \\
\text { ters }\end{array}\end{array}$ & $\begin{array}{l}\text { ALAT } \\
(\mathrm{U} / \mathrm{L})\end{array}$ & $\begin{array}{l}\text { ASAT } \\
(\mathrm{U} / \mathrm{L})\end{array}$ & $\begin{array}{l}\text { Proteins } \\
(\mathrm{g} / \mathrm{dL})\end{array}$ & $\begin{array}{l}\text { Albumin } \\
(\mathrm{g} / \mathrm{dL})\end{array}$ & $\begin{array}{l}\text { T. Bill } \\
(\mathrm{mg} / \mathrm{dL})\end{array}$ & $\begin{array}{l}\text { D. Bill } \\
(\mathrm{mg} / \mathrm{dL})\end{array}$ & $\begin{array}{l}\text { IND Bill } \\
(\mathrm{mg} / \mathrm{dL})\end{array}$ \\
\hline Control & $19.6 \pm 3.9^{\mathrm{A}}$ & $29.6 \pm 4.9^{\mathrm{A}}$ & $7.5 \pm 1.2^{\mathrm{A}}$ & $3.5 \pm 0.3^{\mathrm{A}}$ & $0.7 \pm 0.1^{\mathrm{A}}$ & $0.1 \pm 0.01^{\mathrm{A}}$ & $0.6 \pm 0.01^{\mathrm{A}}$ \\
\hline MEE & $22.6 \pm 3.1^{\mathrm{A}}$ & $27.6 \pm 2.5^{\mathrm{A}}$ & $7.3 \pm 1.8^{\mathrm{A}}$ & $3.7 \pm 0.3^{\mathrm{A}}$ & $0.6 \pm 0.02^{\mathrm{A}}$ & $0.1 \pm 0.01^{\mathrm{A}}$ & $0.5 \pm 0.02^{\mathrm{A}}$ \\
\hline Hypothyroidism & $21.5 \pm 2.5^{\mathrm{A}}$ & $30.5 \pm 1.9^{\mathrm{A}}$ & $6.9 \pm 1.5^{\mathrm{A}}$ & $3.4 \pm 0.2^{\mathrm{A}}$ & $0.7 \pm 0.03^{\mathrm{A}}$ & $0.1 \pm 0.15^{\mathrm{A}}$ & $0.6 \pm 0.2^{\mathrm{A}}$ \\
\hline Hypo+Eltroxin & $26.6 \pm 1.9^{\mathrm{B}}$ & $37.6 \pm 2.0^{\mathrm{B}}$ & $7.1 \pm 2.2^{\mathrm{A}}$ & $3.4 \pm 0.3^{\mathrm{A}}$ & $0.6 \pm 0.1^{\mathrm{A}}$ & $0.1 \pm 0.01^{\mathrm{A}}$ & $0.5 \pm 0.21^{\mathrm{A}}$ \\
\hline Hypo + MEE & $22.0 \pm 2.6^{\mathrm{A}}$ & $30.0 \pm 3.0^{\mathrm{A}}$ & $7.4 \pm 2.0^{\mathrm{A}}$ & $3.5 \pm 0.2^{\mathrm{A}}$ & $0.7 \pm 0.1^{\mathrm{A}}$ & $0.1 \pm 0.05^{\mathrm{A}}$ & $0.6 \pm 0.12^{\mathrm{A}}$ \\
\hline
\end{tabular}

All data are expressed as mean \pm standard error. Data were subjected to one-way ANOVA followed by post hoc Duncan) test. Within the same column, means with different superscript letters are significantly different at $p \leq 0.05$. MEE is Mellisa ethanolic extract, Hypo is Hypothyroidism. 
Table 4. Kidney functions and Calcium level of control, hypothyroidism and hypothyroidism-treated animals groups.

\begin{tabular}{|c|c|c|c|c|}
\hline Groups $\quad$ parameters & $\begin{array}{l}\text { Urea } \\
(\mathrm{mg} / \mathrm{dL})\end{array}$ & $\begin{array}{l}\text { Creatinine } \\
(\mathrm{mg} / \mathrm{dL})\end{array}$ & $\begin{array}{l}\text { Uric } \\
\text { Acid } \\
(\mathrm{mg} / \mathrm{dL})\end{array}$ & $\begin{array}{l}\text { Calcium } \\
(\mathrm{mg} / \mathrm{dL})\end{array}$ \\
\hline Control & $26.0 \pm 4.8^{\mathrm{A}}$ & $0.9 \pm 0.1^{\mathrm{A}}$ & $2.4 \pm 1.8^{\mathrm{A}}$ & $9.5 \pm 0.2^{\mathrm{A}}$ \\
\hline MEE & $25.4 \pm 2.8^{\mathrm{A}}$ & $1.0 \pm 0.1^{\mathrm{A}}$ & $2.6 \pm 1.1^{\mathrm{A}}$ & $9.6 \pm 0.3^{\mathrm{A}}$ \\
\hline Hypothyroidism & $24.0 \pm 2.5^{\mathrm{A}}$ & $0.8 \pm 0.2^{\mathrm{A}}$ & $3.1 \pm 1.2^{\mathrm{B}}$ & $8.6 \pm 0.2^{\mathrm{B}}$ \\
\hline Hypo + Eltroxin $®$ & $26.6 \pm 3.2^{\mathrm{A}}$ & $0.9 \pm 0.2^{\mathrm{A}}$ & $2.9 \pm 1.2^{\mathrm{B}}$ & $9.1 \pm 0.2^{\mathrm{A}}$ \\
\hline Hуро + MEE & $28.5 \pm 1.0^{\mathrm{A}}$ & $1.1 \pm 0.2^{\mathrm{A}}$ & $2.4 \pm 1.9^{\mathrm{A}}$ & $9.0 \pm 0.2^{\mathrm{A}}$ \\
\hline
\end{tabular}

All data are expressed as mean \pm standard error. Data were subjected to one-way ANOVA followed by post hoc Duncan) test. Within the same column, means with different superscript letters are significantly different at $p \leq 0.05$. MEE is Mellisa ethanolic extract, Hypo is Hypothyroidism.

Table 5. Lipid profile levels of control, hypothyroidism and hypothyroidism-treated animals groups.

\begin{tabular}{|c|c|c|c|c|}
\hline Groups parameters & $\begin{array}{l}\text { Cholesterol } \\
(\mathrm{mg} / \mathrm{dL})\end{array}$ & $\begin{array}{l}\text { Triglycerides } \\
(\mathrm{mg} / \mathrm{dL})\end{array}$ & $\begin{array}{l}\mathrm{HDL} \\
(\mathrm{mg} / \mathrm{dL})\end{array}$ & $\begin{array}{l}\mathrm{LDL} \\
(\mathrm{mg} / \mathrm{dL})\end{array}$ \\
\hline Control & $159 \pm 6^{\mathrm{A}}$ & $112 \pm 0.1^{\mathrm{A}}$ & $38 \pm 1.9^{\mathrm{A}}$ & $99 \pm 2.4^{\mathrm{A}}$ \\
\hline MEE & $157 \pm 5^{\mathrm{A}}$ & $111 \pm 0.3^{\mathrm{A}}$ & $36 \pm 2.6^{\mathrm{A}}$ & $99 \pm 2.6^{\mathrm{A}}$ \\
\hline Hypothyroidism & $155 \pm 6^{\mathrm{A}}$ & $117 \pm 0.2^{\mathrm{A}}$ & $40 \pm 2.4^{\mathrm{A}}$ & $92 \pm 3.1^{\mathrm{A}}$ \\
\hline Hypo + Eltroxin ${ }^{\circledR}$ & $152 \pm 8^{A}$ & $115 \pm 0.2^{\mathrm{A}}$ & $39 \pm 3.1^{\mathrm{A}}$ & $90 \pm 2.9^{A}$ \\
\hline Hypo + MEE & $161 \pm 7^{\mathrm{A}}$ & $117 \pm 0.2^{\mathrm{A}}$ & $37 \pm 2.2^{\mathrm{A}}$ & $101 \pm 3.2^{\mathrm{A}}$ \\
\hline
\end{tabular}

All data are expressed as mean \pm standard error. Data were subjected to one-way ANOVA followed by post hoc Duncan) test. Within the same column, means with different superscript letters are significantly different at $p \leq 0.05$. MEE is Mellisa ethanolic extract. 
Table 6. Liver tissue homogenate MDA, NO, GSH, GPx and ATPase levels in control, hypothyroidism, and hypothyroidism-MEE treated animals groups.

\begin{tabular}{|l|l|l|l|l|l|}
\hline \multirow{2}{*}{ Groups parameters } & MDA & NO & GSH & GPx & ATPase \\
\cline { 2 - 6 } & $(\mathrm{nmol} / \mathrm{g})$ & $(\mathrm{nmol} / \mathrm{g})$ & $(\mathrm{nmol} / \mathrm{g})$ & $(\mathrm{nmol} / \mathrm{g})$ & $(\mathrm{nmol} / \mathrm{g})$ \\
\hline Control & $51 \pm 1.1^{\mathrm{A}}$ & $9.8 \pm 1.9^{\mathrm{A}}$ & $1.7 \pm 0.04^{\mathrm{A}}$ & $3035 \pm 110^{\mathrm{A}}$ & $175 \pm 20^{\mathrm{A}}$ \\
\hline MEE & $48 \pm 10.8^{\mathrm{A}}$ & $8.7 \pm 2.0^{\mathrm{A}}$ & $1.9 \pm 0.20^{\mathrm{A}}$ & $2979 \pm 44^{\mathrm{B}}$ & $174 \pm 21^{\mathrm{B}}$ \\
\hline Hypothyroidism & $158 \pm 3.2^{\mathrm{C}}$ & $14.3 \pm 0.8^{\mathrm{B}}$ & $1.1 \pm 0.10^{\mathrm{A}}$ & $2162 \pm 93^{\mathrm{C}}$ & $151 \pm 12^{\mathrm{C}}$ \\
\hline Hypo + Eltroxin $^{(\mathrm{B}}$ & $71 \pm 3.4^{\mathrm{B}}$ & $11.5 \pm 0.7^{\mathrm{B}}$ & $1.5 \pm 0.04^{\mathrm{B}}$ & $3455 \pm 64^{\mathrm{A}}$ & $220 \pm 10^{\mathrm{A}}$ \\
\hline Hypo + MEE & $66 \pm 6.7^{\mathrm{AB}}$ & $10.7 \pm 2.5^{\mathrm{A}}$ & $1.6 \pm 0.02^{\mathrm{AB}}$ & $3574 \pm 181^{\mathrm{A}}$ & $235 \pm 22^{\mathrm{A}}$ \\
\hline
\end{tabular}

All data are expressed as mean \pm standard error. Data were subjected to one-way ANOVA followed by post hoc Duncan) test. Within the same column, means with different superscript letters are significantly different at $p \leq 0.05$. MEE is Mellisa ethanolic extract, Hypo is Hypothyroidism.

Table 7. Kidney tissue homogenate MDA, NO, GSH, GPx and ATPase levels in control, hypothyroidism and hypothyroidism-MEE treated animals groups.

\begin{tabular}{|l|l|l|l|l|l|}
\hline \multirow{2}{*}{ Groups parameters } & MDA & NO & GSH & GPx & ATPase \\
\cline { 2 - 6 } & $(\mathrm{nmol} / \mathrm{g})$ & $(\mathrm{nmol} / \mathrm{g})$ & $(\mathrm{nmol} / \mathrm{g})$ & $(\mathrm{nmol} / \mathrm{g})$ & $(\mathrm{nmol} / \mathrm{g})$ \\
\hline Control & $96 \pm 7^{\mathrm{A}}$ & $14 \pm 0.3^{\mathrm{A}}$ & $1.8 \pm 0.0^{\mathrm{A}}$ & $3257 \pm 59^{\mathrm{A}}$ & $153 \pm 5^{\mathrm{A}}$ \\
\hline MEE & $89 \pm 7^{\mathrm{A}}$ & $15 \pm 1.4^{\mathrm{C}}$ & $1.7 \pm 0.02^{\mathrm{A}}$ & $3347 \pm 87^{\mathrm{B}}$ & $157 \pm 6^{\mathrm{B}}$ \\
\hline Hypothyroidism $^{*}$ & $154 \pm 4.3^{\mathrm{C}}$ & $25 \pm 0.9^{\mathrm{B}}$ & $1.2 \pm 0.03^{\mathrm{C}}$ & $2862 \pm 197^{\mathrm{A}}$ & $140 \pm 14^{\mathrm{A}}$ \\
\hline Hypo + Eltroxin $^{(B)}$ & $81 \pm 11^{\mathrm{B}}$ & $23 \pm 0.9^{\mathrm{A}}$ & $1.5 \pm 0.03^{\mathrm{B}}$ & $2988 \pm 426^{\mathrm{C}}$ & $166 \pm 10^{\mathrm{C}}$ \\
\hline Hypo + MEE & $78 \pm 14^{\mathrm{B}}$ & $17 \pm 1.4^{\mathrm{D}}$ & $1.6 \pm 0.01^{\mathrm{B}}$ & $3064 \pm 253^{\mathrm{C}}$ & $186 \pm 5^{\mathrm{B}}$ \\
\hline
\end{tabular}

All data are expressed as mean \pm standard error. Data were subjected to one-way ANOVA followed by post hoc Duncan) test. Within the same column, means with different superscript letters are significantly different at $p \leq 0.05$. MEE is Mellisa ethanolic extract, Hypo is Hypothyroidism.

\section{Discussion}

Thyroid hormones have an important role in the regulation of energy metabolism and mitochondrial activity Martinez et al (2001). Propylthiouracil (PTU) is a thioamide anti-thyroid drug. It has been used in the treatment of hyperthyroidism for more than half a century; it can induce a hypothyroidism status Sener et al (2006). So it has been frequently used to create an animal model of hypothyroidism Hapon et al (2003).

In hypothyroid model, serum concentrations of total triiodothyronine (T3), total thyroxine (T4), free triiodothyronine (FT3) and free thyroxine (FT4) were significantly decreased, and serum thyroid-stimulation hormone (TSH) concentration was markedly 
increased than in normal rats. Our results revealed a significant increase in TSH, accompanied with significant decrease in thyroid hormones these findings go with the results of Umezu et al (2016) who suggested that PTU performing its anti-thyroid effects through inhibiting the iodine oxidation and ionization of the monoiodotyrosine, preventing the coupling stage in the process of thyroxin production, so it suppresses thyroid hormones synthesis by blocking thyroid peroxidase activity Fumarola et al (2010).

Hypothyroidism is a state of increased oxidative stress, MDA and NO is a marker of lipid peroxidation, to measure oxidative stress Baskol et al (2007). Our results showed marked increase in both liver and kidney MDA and NO levels in hypothyroid modeled rats; this result is in accordance with the results of Dardano et al (2006) and Coria et al (2009).

Different defensive mechanisms that protect against the free radical damage have been characterized in various cellular localizations, including the endoplasmic reticulum, mitochondria, plasma membrane, peroxisomes and cytosol Littarru et al (1994). Enzymes such as GSH, GPx, ATPase and transition-metal binding proteins, such as transferrin, ferritin (that considered as iron carrier), prevent the production of inactivate free radicals, so GPx activity and other antioxidants as GSH decreased during hypothyroidism as antioxidants and also accompanied with hemoglobin deficiency as a result to ferritin depletion Baltaci et al (2014) these results are matches with the present study that show an increase in the level of livers' and kidneys' MDA and NO; this could be due to hypothyroidism-induced oxidative stress and a decrease level of GPx, ATPase and GSH and hemoglobin (ferritin) as antioxidants or free radical scavenging agents when compared with control group.

It was reported that serum level of ASAT and ALAT were markedly increased in hypothyroidism Umezu et al (2016). Liver aminotransferases abnormality, that might indicate subclinical liver injury, is a common event after PTU administration Liaw et al (1993) and Carrion et al (2010). PTU was found to increase the voltage of oxidative stress that affect hepatocyte integrity and causes an minimal increase in serum liver enzymes (ALAT and ASAT) accompanied by minimal depletion in serum total protein and albumin in hypothyroidism molded animals when compared with normal ones.

In the present study showed non-significant in Serum total and direct bilirubin levels while the result in contrary with increased Serum total and direct bilirubin levels due to PTU and hypothyroidism; these results are cope with Williams et al (1993). Similarly, PTU-induced hypothyroidism had been reported to be accompanied by low a renal changes in serum creatinine and urea levels; in addition, the results of this study showed decreasing in serum calcium level matched with a significant increase in serum level of uric acid when compared with the control group. These changes might be due to PTU-induced renal toxicity and are agreed with the results of Sarandol et al (2005).

The thyroid gland plays a critical role in the synthesis of fatty acids and the degradation of lipids Wang et al (2008); therefore, thyroid dysfunction is often associated with weight gain and elevated glucose levels Pucci et al (2000) and Luño et al (2015). Our results coordinate with that results which indicate an increase in body weight and minimal increasing in glucose levels. 
Serum level of total cholesterol, triglycerides and LDL was raised significantly coupled with a marked reduction in serum HDL as a consequence to hypothyroidism; this could be attributed to the elevated oxidative stress monitored from the significant raise in hepatic and renal lipid peroxidation (MDA) levels Erdem and Kara (2015). In contrary In the present study treatment of normal or hypothyroidism rats with MEE or Eltroxin ${ }^{\circledR}$ did not deteriorate serum total cholesterol, triglycerides, HDL or LDL values when compared with control group may be causing short term of experiment.

In the recent years, importance is being given to herbal plants due to their effective therapeutic action and minimal side effects. Melissa officinalis is a plant cultivated in some parts of Iran. Its leaves are used in Iranian folk medicine for management of many disorders as it has high capacity of antioxidant properties through its chemical compounds including high amount of flavonoids, rosmaric acid, gallic acid and phenolic contents Miraj et al (2017). Many studies demonstrated that the cytoprotective effect of lemon balm extracts seen in rats was partly due to free radical scavenging properties Luño et al (2015). Moreover, it could protect against oxidative damage induced by various pro-oxidant agents that induce lipid peroxidation by different processes. Thus, plant extracts could inhibit the generation of early chemical reactive species that subsequently initiate lipid peroxidation or, alternatively, they could block a common final pathway in the process of polyunsaturated fatty acids peroxidation, Dastmalchi et al (2008). consequently it was able, herein, to reduce liver and kidney MDA and NO. Also, it was reported that Melissa (Lemon balm) improves plasma levels of glutathione hormone and glutathione peroxidase and ATPase with a marked reduction in lipid peroxidation. Due to its iron (II) chelating activity, the extracts' antioxidant potential was increased Dastmalchi et al (2008).

Melissa officinalis containing flavonol glycosides and biflavone aglycones or chlorogenic acid type phenolics present in MEE, were responsible for the free radical scavenging activity; consequently the induced lipid peroxidation in rat significantly inhibited Ferreira et al (2006). Melissa officinalis L containing essential oils have good potential for antioxidant activity, It is a rich source of antioxidants, in particular from the group of phenolic compounds Capecka et al (2005) that can improve thyroid hormones; this result is in line with that of Yu et al (2018).

The results of this study suggested that $M$. officinalis extract decreased serum ASAT \& ALAT as well as liver ATPase. This could be attributed to that M. officinalis is possessing strong antioxidant properties as it contains bioactive polyphenolic compounds Pereira et al (2009). that are among the most important anti-oxidants with ability to stabilize (through a mechanism of electron donation to the reactive radicals or oxygen species) and scavenge the oxidative radicals, consequently restore, not only liver functions but also, kidney functions; so serum creatinine, urea, uric acid and calcium levels improved. These results go with the results of many previous studies Carreón et al (2002); Ahmad et al (2002); Yoshikava et al (2003); Pyo et al (2004).

Active free radicals, such as superoxide anions and hydroxyls, are capable of removing hydrogen atoms from the peripheral chains of saturated fatty acids in biologic membranes and resulting in lipid peroxidation (Kelly and Husband (2003) ; Nazari et al (2005). 
M. officinalis has compounds that can inhibit lipid peroxidation and its extract was found able to stabilize cell membrane and prevents the oxidation of membrane lipids; therefore, it reduced both renal and hepatic levels of MDA and NO. Also, polyphenolic compounds and flavonoids present in MEE can also revive the cells against glutathione depletion and protect them by increasing the capacity of anti-oxidant buttery as it succeeded in restoring both liver and kidney glutathione level as well as the activity of glutathione reductase, glutathione peroxidase and catalase (Sanz et al (1998); Al-Qarawi et al (2002); results are cope with the results of Saija et al (1995\& 2005) and Pereira et al (2009).

Our results illustrated that indicated that MEE ameliorated total cholesterol, triglycerides, LDL cholesterol and HDL serum level; this finding agonist that of Pereira et al (2009) and Ashtiyani et al (2011); this result confirmed, in self, by the reduction in lipid peroxidation (MDA and NO) level in both liver and kidney tissues; Moreover, by the increased glutathione hormone, glutathione peroxidase and ATPase levels in both tissues. These results are in accordance with Bolkent et al (2005). Also, the study showed improvement in the body weight gain and blood glucose level; and are in agreement with the results of Ali et al (2014).

In conclusion, The present investigation confers new information on the ameliorative mechanism of the Melissa officinalis ethanolic extract (MEE) against PTUinduced hypothyroidism; this anti-hypothyroidism therapeutic potential could be attributed to the ability of MEE to attenuate the oxidative stress, inhibit lipid peroxidation, prevent GSH decline and enhance the enzymatic antioxidant defenses therefore, ameliorate the binding capacity of iodine in the thyroid tissue.

\section{REFERENCE}

Ahmad A, Ahmad N, and Shah S, (2013). Role of packaging in consumer buying behavior. International Review of Basic and Applied Sciences, 1, 35-41.

Ahmad K, and Henikoff S. (2002). Epigenetic consequences of nucleosome dynamics. Cell, 111, 281-284.

Akhondzadeh S, Noroozian M, Mohammadi M, Ohadinia S, Jamshidi AH, and Khani M (2003). Melissa officinalis extract in the treatment of patients with mild to moderate Alzheimer's disease: a double blind, randomised, placebo controlled trial. Journal of Neurology, Neurosurgery \& Psychiatry, 74, 863-866.

Ali Q, Ali A, Waseem M, Muzaffar A, Ahmad S, Ali S, and Tayyab H. (2014). Correlation analysis for morpho-physiological traits of maize (Zea mays L.). Life Science Journal, 11, 9-13.

Allain CC, Poon LS, Chan CS, Richmond WFPC, and Fu PC (1974). Enzymatic determination of total serum cholesterol. Clinical chemistry 20, 470-475.

Al-Qarawi AA, Al-Homidan A, Al-Waily SA, and Adam SEI. (2002). Response of broiler chicks to dietary Rhazya stricta and Nigella sativa. British poultry science, 43, 291-296. 
Ashtiyani SC, Shamsi M, Cyrus A, Bastani B, and Tabatabayei SM. (2011). A critical review of the works of pioneer physicians on kidney diseases in ancient Iran: Avicenna, Rhazes, Al-akhawayni, and Jorjani. Iranian journal of kidney diseases, 18, 5, 300 .

Baltaci AK, Mogulkoc R, Ayyildiz M, Kafali E, Koyuncuoglu T (2014). Lipid peroxidation in kidney and testis tissues in experimental hypothyroidism: the role of zinc. Bratisl Lek Listy 115, 498-501.

Barham D, Trinder P (1972). An improved colour reagent for the determination of blood glucose by the oxidase system. Analyst, 97, 142-145.

Baskol G, Atmaca H, Tanriverdi F, Baskol M, Kocer D, and Bayram F. (2007). Oxidative stress and enzymatic antioxidant status in patients with hypothyroidism before and after treatment. Experimental and clinical endocrinology and diabetes, 115, 522-526.

Berger S, and Tietz NW. (1976). Fundamentals of clinical chemistry. Saunders. Vision Research, 16, 839-845.

Bergmeyer HU, Herder M., and Ref R (1986). International federation of clinical chemistry (IFCC). J. Clin. Chemistry. Clinical. Biochemistry, 24, 497-510.

Beutler E (1963). Improved method for the determination of blood glutathione. Journal laboratory clinical Medicine, 61, 882-888.

Bolkent S, Yanardag, R, Karabulut-Bulan O, and Yesilyaprak B. (2005). Protective role of Melissa officinalis L. extract on liver of hyperlipidemic rats: a morphological and biochemical study. Journal of Ethnopharmacology, 99, 391398.

Cachefo ANA, Boucher P, Vidon C, Dusserre E, Diraison F, and Beylot M. (2001). Hepatic lipogenesis and cholesterol synthesis in hyperthyroid patients. The Journal of Clinical Endocrinology \& Metabolism, 86, 5353-5357.

Capecka E, Mareczek A, and Leja M. (2005). Antioxidant activity of fresh and dry herbs of some Lamiaceae species. Food chemistry, 93, 223-226.

Carreón-Rodríguez VG, Sesma-Vázquez S, Campuzano-Rincón JC, Knaul, F, LópezAntuñano FJ, and Hernández-Avila, M. (2002). El comportamiento de la demanda de tabaco en México: 1992-1998. salud pública de méxico, 44, 82-92.

Carrion AF, Czul F, Arosemena LR, Selvaggi G, Garcia MT, and Tekin A. (2010). Propylthiouracil-induced acute liver failure: role of liver transplantation. International journal of endocrinology, 2010, 1-6.

Coria MJ, Pastrán AI and Gimenez M. (2009). Serum oxidative stress parameters of women with hypothyroidism. Acta Biomedica Atenei Parmensis. 80,135-139

Dardano A, Caraccio N, Ghiadoni L, Ghiadoni L, Taddei S, Virdis A, and Versari D. (2006). Low-grade systemic inflammation causes endothelial dysfunction in 
patients with Hashimoto's thyroiditis. The Journal of Clinical Endocrinology and Metabolism, 91, 5076-5082.

Dardano A, Ghiadoni L, Plantinga Y, Caraccio N, Bemi A, Duranti E, and Monzani, F. (2006). Recombinant human thyrotropin reduces endothelium-dependent vasodilation in patients monitored for differentiated thyroid carcinoma. The Journal of Clinical Endocrinology \& Metabolism, 91, 4175-4178.

Dastmalchi K, Dorman HD, Oinonen PP, Darwis Y, Laakso I, and Hiltunen R. (2008). Chemical composition and in vitro antioxidative activity of a lemon balm (Melissa officinalis L.) extract. LWT-Food Science and Technology, 41, 391-400.

Doumas BT, Watson WA, and Biggs HG (1971). Albumin standards and the measurement of serum albumin with bromcresol green. Clinical chemistry Acta, 31, 87-96.

Draper HH, and Hadley M (1990). Malondialdehyde determination as index of lipid Peroxidation. In Methods in enzymology ,186, 421-431.

Erdem C, and Kara A. (2015). Towards real time implementation of specific emitter identification on pulse waveforms: optimizations on a low cost commercial platform,2,63.

Fossati P, and Prencipe L (1982). Serum triglycerides determined colorimetrically with an enzyme that produces hydrogen peroxide. Clinical chemistry, 28, 2077-2080.

Fumarola A, Di Fiore A, Dainelli M, Grani G, and Calvanese A (2010). Medical treatment of hyperthyroidism: state of the art. Experimental Clinical Endocrinol,10,118, 678.

Gosh RC, Sawale, GK, Maini S, and Rekhe DS. (2009). Experimental Mycotoxicosis in layer induced by ochratoxin $\mathrm{A}$ and its amelioration with herbominieral toxin binder Toxiroak . International Journal of Poultry Science, 8, 798-803.

Habig W, Babst M, and Jakooby WJ. (1974). Bio-Diagnostic . Chemistry, 249,71307139.

Hapon MB, Simoncini M, Via G, and Jahn GA (2003). Effect of hypothyroidism on hormone profiles in virgin, pregnant and lactating rats, and on lactation. Reproduction 126,371-382

Ikeuchi T, Kohno A, Nakae T, Umezu M, and Kodaka Y. (2016). U.S. Patent No. Washington, DC: U.S. Patent and Trademark Office. 9,322-659.

Judith S, and Main M. (1990). Procedures for Identifying infants as disorganized during the Anisworth Strange Situation . Attachment in preschool years : Theory, research, and Intervention, 1, 121-160.

Kelly GE, and Husband AJ. (2003). Flavonoid compounds in the prevention and treatment of prostate cancer. In Prostate Cancer Methods and Protocols, 10,377394. 
Liaw YF, Huang MJ, Fan KD, Li KL, Wu SS, and Chen TJ 1993. Hepatic injury during propylthiouracil therapy in patients with hyperthyroidism: a cohort study. Ann Intern Med. 118,424-428.

Littarru GP,Mancini A, Conte B, De Marinis L, Hallgass ME, Pozza D, and Oradei A,. (1994). Coenzyme Q10 levels in human seminal fluid: diagnostic and clinical implications. Molecular aspects of medicine, 15, 249-594.

Luño V, Gil L, Olaciregui M, Jerez RA, de Blas I, Hozbor F (2015). Antioxidant effect of lemon balm (Melissa officinalis) and mate tea (Ilex paraguensys) on quality, lipid peroxidation and DNA oxidation of cryopreserved boar epididymal spermatozoa. Andrologia,47, 1004-1011.

Martinez B, Hoyo P, Martin MA, Arenas J, Perez-Castillo A, and Santos A (2001). Thyroid hormone regulates oxidative phosphorylation in the cerebral cortex and striatum of neonatal rats. J Neurochem 78, 1054-1063.

Miraj S, Azizi N, and Kiani S (2016). A review of chemical components and pharmacological effects of Melissa officinalis L. Der Pharmacia Lettre, 8, 229237.

Miraj S, Rafieian-Kopaei, and Kiani S. (2017). Melissa officinalis L: A Review Study With an Antioxidant Prospective. Journal of evidence-based complementary and alternative medicine, 22, 385-394.

Montgomery H, and Dymock JF (1961). Determination of nitrite in water. Analyst, 86, 414.

Nazari A, Delfan B, and Shahsavari GH. (2005). The effect of Satureja khuzestanica on triglyceride, glucose, creatinine and alkaline phosphatase activity in rat. Journal of Shahrekord Uuniversity of Medical Sciences, 7, 1-8 .

Newman DE, and Price CP. (2001). Using the R/S statistic to analyze AE data. Journal of Atmospheric and Solar-Terrestrial Physics, 63, 1387-1397.

Panda S, and Kar A (2005). Guggulu Commiphora mukul potentially ameliorates hypothyroidism in female mice. Phytotherapy Research: An International Journal Devoted to Pharmacological and Toxicological Evaluation of Natural Product Derivatives, 19, 78-80.

Pereira FL, Gash JHC, David JS, David TS, Monteiro PR, and Valente F (2009). Modelling interception loss from evergreen oak Mediterranean savannas: application of a tree-based modelling approach. Agricultural and Forest Meteorology, 149, 680-688.

Pucci E, Chiovato L, and Pinchera A (2000). Thyroid and lipid metabolism. Intl J Obes Related Metb Dis. 24,109-112.

Pyo YH, Lee TC, Logendra L, and Rosen RT. (2004). Antioxidant activity and phenolic compounds of Swiss chard (Beta vulgaris subspecies cycla) extracts. Food chemistry, 85, 19-26. 
Reza Heidari, Niknahad H, Jamshidzadeh A, Eghbal MA, and Abdoli N. (2014). An overview on the proposed mechanisms of antithyroid drugs-induced liver injury. Advanced pharmaceutical bulletin, 5,1 .

Saija A, Scalese M, Lanza M, Marzullo D, Bonina F, and Castelli F. (1995). Flavonoids as antioxidant agents: importance of their interaction with biomembranes. Free Radical Biology and Medicine, 19, 481-486.

Saija A, Tomaino A, Cimino F, Zimbalatti V, Venuti V, Sulfaro V, and De Pasquale A. (2005). Influence of heating on antioxidant activity and the chemical composition of some spice essential oils. Food chemistry, 89, 549-554.

Sanz-Guajardo D, Jofre R, López-Gómez JM, Moreno F, and Valderrábano F. (1998). Changes in quality of life after renal transplantation. American Journal of Kidney Diseases, 32, 93-100.

SarandöI E, Taş S, Dirican M, and Serdar Z. (2005). Oxidative stress and serum paraoxonase activity in experimental hypothyroidism: effect of vitamin $\mathrm{E}$ supplementation. Cell Biochemistry and Function: Cellular biochemistry and its modulation by active agents or disease, 23, 1-8.

Sener G, Kabas akal L, Atasoy B M, Erzik C, Velioglu-Ogunc A, Cetinel S, Yegen BC (2006) .Propylthiouracil-induced hypothyroidis protects ionizing radiation-induced multiple organ damage in rats. J Endocrinol 189, 257-269.

Smallridge RC, and Ladenson PW (2001). Hypothyroidism in pregnancy: consequences to neonatal health. The Journal of Clinical Endocrinology \& Metabolism, 86, 2349-2353.

Tietz NW. (1994). Accuracy in clinical chemistry--does anybody care?. Clinical chemistry, 40, 859-861.

Tietz, N. W. (1995). Clinical guide to laboratory tests. WB Saunders Co,3,268-273.

Umezu M, Ikeuchi T, Kohno A, Nakae T, and Kodaka Y. (2016). U.S. Patent No. Washington, DC: U.S. Patent and Trademark Office. 9,322-659.

Wake N. (2000). Long-term results of the Kumamoto Study on optimal diabetes control in type 2 diabetic patients. Diabetes care, 23, 21-29.

Wang Y, Beydoun MA, Liang L, Caballero B, Kumanyika SK (2008). Will all Americans become overweight or obese? estimating the progression and cost of the US obesity epidemic. Obesity 16,2323-2330.

Warnick GR, and Wood PD. (1995). National Cholesterol Education Program recommendations for measurement of high-density lipoprotein cholesterol: executive summary. The National Cholesterol Education Program Working Group on Lipoprotein Measurement. Clinical chemistry, 41, 1427-1433.

Williams JM, Dawson GJ, Frost CG, Martin CJ, and Coote SJ. (1993). Sulfides tethered to oxazolines: ligands for enantioselective catalysis. Tetrahedron letters, 34, 7793-7796. 
Williams KV, Nayak S, Becker D, Reyes J, Burmeister LA (1997). Fifty years of experience with propylthiouracil-associated hepatotoxiCity: what have we learned J Clin Endocrinol Metab. 82,1727-1733.

Yoshikawa A, Park JS, Park HJ, Hahn YB, and Yi GC. (2003). Dry etching of ZnO films and plasma-induced damage to optical properties. Journal of Vacuum Science \& Technology B: Microelectronics and Nanometer Structures Processing, Measurement, and Phenomena, 21, 800-803.

Young LJ, Lim MM, Gingrich B, and Insel TR. (2001). Cellular mechanisms of social attachment. Hormones and behavior, 40, 133-138.

Yu Y. (2018). Washington, DC: U.S. Patent and Trademark Office, 9 , 1 -22 .

Zarei A, Ashtiyani SC, Taheri S, and Rasekh F. (2014). Comparison between effects of different doses of Melissa officinalis and atorvastatin on the activity of liver enzymes in hypercholesterolemia rats. Avicenna journal of phytomedicine, 1, 4, 15.

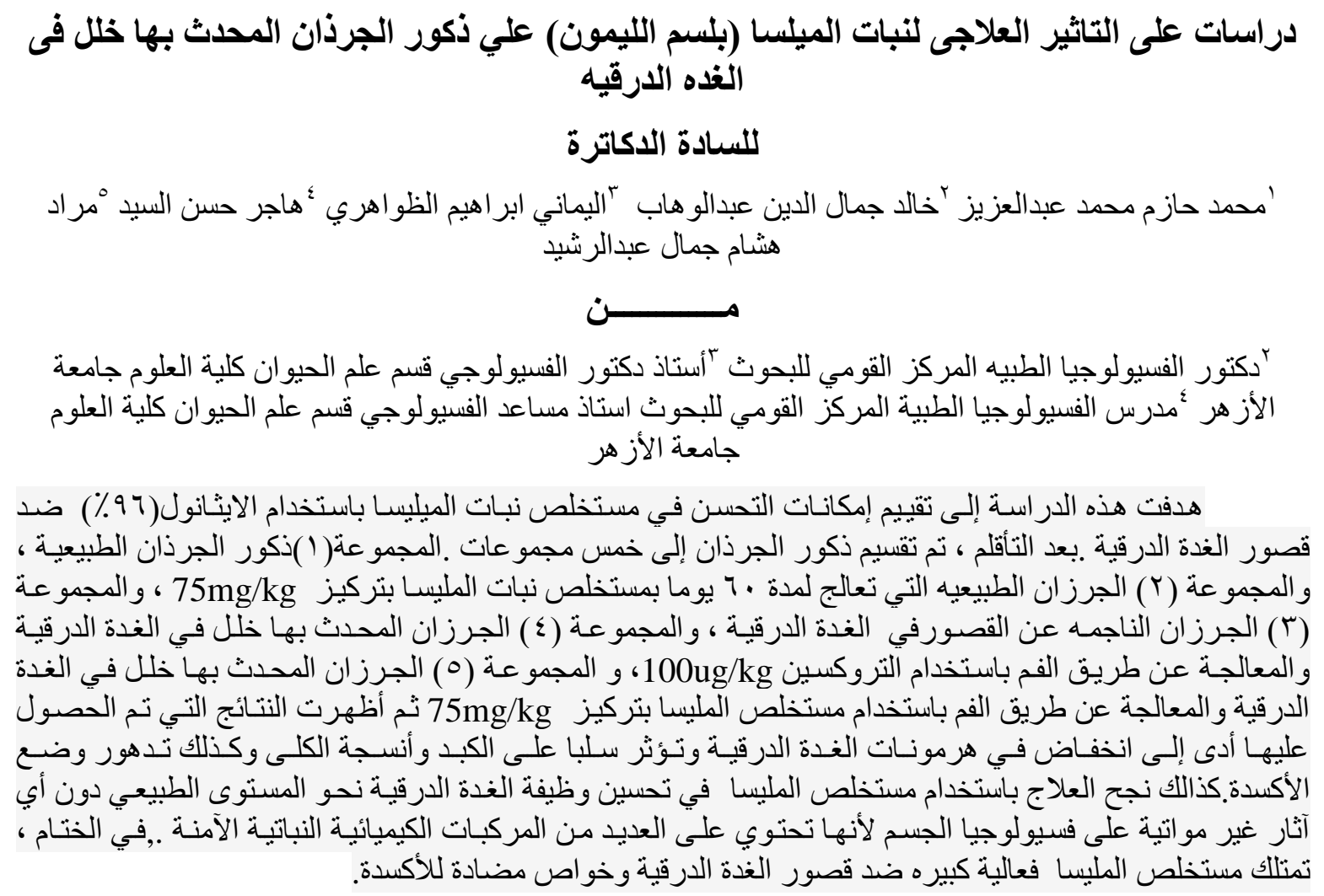

